\title{
Adolescents Influence in Family Decision Making
}

\author{
*Sri. Rajesh Kumar Sain, *Mr. Jaya Prakash Rath \\ Dept. of Management Ravenshaw University, India \\ Dept. of Management Ravenshaw University, India
}

\begin{abstract}
The primary purpose of studying consumer behavior is to understand why and how consumers make their purchase decisions. In all marketing decision making, it is relevant and important for any business to understand the consumer and his buying behavior. It is also important for any business to understand the consumer and his buying behavior. It is also important to understand how buying decisions are taken, as marketing starts with the analysis of consumer behavior. To gain a better understanding of the complex buying behavior, the marketers need to take the cues from the various disciplines, such as economics, psychological factors. The consumer behavior models describe to decision making or choice processes of consumer knowledge and how individuals and family units make consumption decision.
\end{abstract}

Key Words: Behavior, Choice, Cues, Decision, Models

\section{Introduction}

This topic has dealt with the intricacies of "Consumer Behavior", "Decision Making Process", "Family Decision Making Process", "Adolescent's Influence In Family Decision Making”, "Gender Differences And Its Effect On The Decision Making", "Goods Base Differences", "Brand Based Differences", "Income Based Differences", "Area Wise Differences", "Age Wise Differences" and many more delicate issues which has unrevealed a range of new findings that is of immense help to the consumer durable market of this region. The questionnaire has been prepared giving due emphasis to the various age group, various income group and the parental as well as adolescents response to the questions on the pre-purchase, purchase and post purchase behavior.

Again the influence of the adolescents to this purchase has been vividly described with proper statistical analysis (Like Chi-square Test, Z-Test etc...). This survey gave a close look at the real life situation and the influence of adolescents in the purchase of consumer durable. The model of consumer decision making has been thoroughly tested and fitted with the real life situations and the variations from these models also described. This survey has a great significance to the seller of consumer durable, to the ad agencies and to various other members of the society who does this directly or indirectly affects. In fact each and household are affected by this decisions. So, the work done through this survey has of great value to the whole society. This survey has been done with proper care so that it can give a true and fair picture of the adolescent's influence.

\section{Review of Litrature}

The studies of Blood and Wolf (1960) reveled that their resources positively affect an adolescent's influence.William D. Perreault Jr. and Frederick A. Russ (1971) have reported that college students often attempted to influence decision concerning the purchase of television sets and automobiles. Ward and Wackman (1972) pointed out in their studies that children have the greatest influence over categories like snackfoods, candy and toys. They have little direct influence over products normally associated with adults, such as autos and household items and even children may exert some influence on adult items as well. Again they found that mother act as final decision-maker more often then the socializing agent. Ronald W. Stampft (1978) observed that in the child hood stage of consumer life cycle the parents provide all needs to the children. They have very knowledge of the product and the market place.

\section{Objectives}

1. To assess the adolescent influence on family purchase decision-making across a selected consumer durable.

2. To ascertain the degree of influence of male or female adolescent in the family purchase decision making.

3. To study the extent of influence played by the adolescent at different stages of buying process.

\subsection{Data Collection}

\section{Methodology}

The present study is based mostly on primary data. Data from respondents were obtained through the survey method. Respondents chosen for the study are adolescents (both male and female) and the parents. 
Secondary sources were also taken help of for giving a theoretical overview of consumer behavior and family decision making.

Instruments used for data collection :

Survey method was followed to collect primary data. The questionnires contained both open and closed ended questions. In depth interviews were also conducted with a few respondents by using extensive probing to get a single respondent to talk freely and to express beliefs and feelings on different aspects of family purchase decisions.

\subsection{Data Analysis}

$\mathrm{H} 01$ = relative influence of adolescents on the decision making process for durable for the adolescents.

The null hypothesis is tested with help of chi quare test 100 number of dual income families and 100

single income families for the consumer durable products covered under the study presented below.

Observed Frequency Table

\begin{tabular}{|l|c|c|c|}
\hline \multicolumn{1}{|c|}{ Families/Product } & Dual Income & Single Income & Total \\
\hline Refrigerator & 15 & 10 & 25 \\
\hline Audio system & 18 & 19 & 37 \\
\hline TV & 22 & 21 & 43 \\
\hline Telephone & 16 & 13 & 29 \\
\hline Two wheeler & 11 & 20 & 31 \\
\hline Four wheeler & 18 & 17 & 35 \\
\hline Total & 100 & 100 & 200 \\
\hline
\end{tabular}

Chi Square Table

\begin{tabular}{|l|c|c|c|}
\hline \multicolumn{1}{|c|}{$\mathrm{O}$} & $\mathrm{E}$ & $(\mathrm{O}-\mathrm{E})^{2}$ & $(\mathrm{O}-\mathrm{E})^{2} / \mathrm{E}$ \\
\hline 15 & 13 & 4 & .03 \\
\hline 18 & 19 & 1 & .05 \\
\hline 22 & 21 & 1 & .04 \\
\hline 16 & 14 & 4 & .28 \\
\hline 11 & 15 & 16 & 1.06 \\
\hline 18 & 17 & 1 & .05 \\
\hline 10 & 12 & 4 & .33 \\
\hline 19 & 18 & 1 & .05 \\
\hline 21 & 22 & 1 & .04 \\
\hline 13 & 15 & 4 & .26 \\
\hline 20 & 16 & 16 & .00 \\
\hline 17 & 18 & & 3.24 \\
\hline TOTAL & & & \\
\hline
\end{tabular}

Where $\mathrm{O}$ - observed frequency

$$
\begin{aligned}
& \mathrm{E}=\text { expected frequency } \\
& \mathrm{X}^{2}=\Sigma(\mathrm{O}-\mathrm{E})^{2} / \mathrm{E}=3.24
\end{aligned}
$$

The degree of freedom " $\mathrm{v}$ " $=(\mathrm{r}-1)(\mathrm{c}-1)=(6-1) \times(2-1)=5$

At $5 \%$ level of significance the tabulated value of chi square $=11.07$

As calculated value of $\mathrm{x}^{2}<$ table value of $\mathrm{x}^{2}$ at $5 \%$ level of significance the null hypotheses is accepted.

$\mathrm{H}_{02}$ : $\quad$ adolescent influence is undifferentiated with the positive attitude towards products or brand.

This hypothesis has been derived after analysing 100 adolescent respondent and they're influencing attitude towards the product with the help of " $Z$ test".

$\mathrm{Z}$ test

$X=57 \%$ (as $57 \%$ of parents "always positively" influenced by adolescent)

$\mathrm{p}=$ probable number of negative influence

$\mathrm{q}=1-\mathrm{p}$

$\mathrm{Z}=\mathrm{X}-\mathrm{np} / \sqrt{ } \mathrm{npq}=57-50=7 / 5=1.4$

$\sqrt{ } 100 \times 1 / 2 \times 1 / 2$
Here the degree of freedom " $v$ " $=(\mathrm{r}-1)(\mathrm{c}-1)=(4-1) \times(2-1)=3$

The level of significance at $5 \%$ the tabulated value is 1.96 .

As tabulated value (1.96) is greater then the calculated value the hypothesis is "accepted". 


\section{Conclusion}

At the close of the study, an attempt is made to piece together the scattered threads of the analysis to form a coherent picture of the adolescent influence in family purchase decision making.Families and organization rather than individuals make many purchase decisions. Family is decision-making unit with prescribed roles and purchase influence. Family members can perform the role of information gatherer, influencer, decision-maker, buyer and user/consumer. Family decision making is strongly influenced by the individuals involved, the products class and the purchse situation. Out of both parents (husband and wife) and the children, the parents are usually the dominant influencers in family decision making. The influence of husband and wife and the children very according to the characteristic. Generally children rely more on their peer groups, as they grow older. Similarly, members serve as information gatherer, influencers and decisionmakers to interactiobn with the child. The mother's primary role facilities the final decision, either by letting the child buy what is wanted or blocking the purchase.

\section{References}

[1]. Achumba, I. C. (2006). The Dynamics of Consumer Behaviour, (New ed.). Lagos: Mac-Williams

[2]. A.Holdway,Delighting Customer: understanding needs starts with employees, S A M Advance Management Journal,63(1),27-35,2001.

[3]. Bob E.Hayes, Measuring Customer Satisfaction: Survey Design, Use and Statistical Analysis Methods, $2^{\text {nd }}$ Edition, ASQ Quality Press, Milwaukee, Wisconsin, 1998

[4]. Harris E. \& Strout, E, Keeping Customer Happy, Sales and Marketing Management, April,153(4),69,2001.

[5]. J.A.Howard and J.N.Sheth, The Theory of Buyer Behaviour, New York, John Wiley and Sons; 1969.

[6]. Philip Kotler, "Marketing Management: Analysis Planning Implementation and Control", (New Delhi: Prentice Hall), 1991. 